\title{
УЛЬТРАЗВУКОВЕ ДОСЛІДЖЕННЯ ОРГАНІВ ЧЕРЕВНОЇ ПОРОЖНИНИ У ПАЦІЕНТТВ ЗА СПАЙКОВОЇ ХВОРОБИ ОЧЕРЕВИНИ
}

\author{
Д. О. Євтушенко \\ Харківський національний медичний університет, \\ Інститут загальної та невідкладної хірургії імені В. Т. Зайцева НАМН України, м. Харків

\section{ULTRASONOGRAPHIC INVESTIGATION OF ABDOMINAL ORGANS IN PATIENTS, SUFFERING ADHESIVE PERITONEAL DISEASE}

\author{
D. O. Evtushenko \\ Kharkiv National Medical University, \\ Zaytsev Institute of General and Urgent Surgery, Kharkiv
}

\begin{abstract}
Реферат
Використання ультразвукового дослідження (УЗД) розширює можливості діагностики спайкової хвороби очеревини (СХО), вибору доступу й методики хірургічного втручання у хворих. Для дослідження у 290 хворих використовували апарат ESAOTE MyLabAlpha (Італія). За допомогою УЗД СХО виявлена у 94,1\% хворих, його проведення в динаміці дозволило контролювати і своєчасно визначати показання до оперативного втручання. У хворих за динамічної непрохідності кишечнику повторне проведення УЗД дозволило уникнути виконання непотрібної релапаротомії. Використання УЗД в клінічній практиці сприяло виявленню ознак СХO, акустичного вікна для введення троакара під час виконання мініінвазивного втручання.

Ключові слова: спайкова хвороба очеревини; діагностика; ультразвукове дослідження.

Abstract

Application of ultrasonographic investigation(USGI) extends possibilities of the adhesive peritoneal disease (APD) diagnosis as well as the disease operative access and procedure choice. Apparatus ESAOTE MyLabAlpha (Italy) was used while examining 290 patients. With the help of USGI APD was revealed in $94.1 \%$ of patients, and its conduction in dynamics have permitted to control and determine timely the indications for operative treatment. In patients, suffering dynamic ileus, reconduction of USGI have permitted to avoid the performance of unnecessary relaparotomy. Application of USGI in clinical practice have promoted the APD signs revealing as well as acoustic window for introduction of trocar during performance of miniinvasive intervention.

Keywords: adhesive peritoneal disease; diagnosis; ultrasonographic investigation.
\end{abstract}

Проблема СХО надзвичайно актуальна в хірургічній практиці. Спайки очеревини у $40-75 \%$ хворих спричиняють непрохідність кишечнику, летальність за цього ускладнення досить висока (5 - 10\%) і немає тенденції до зменшення. Необхідність дослідження СХО збільшується через постійне збільшення частоти виконання та обсягу операцій на орга-

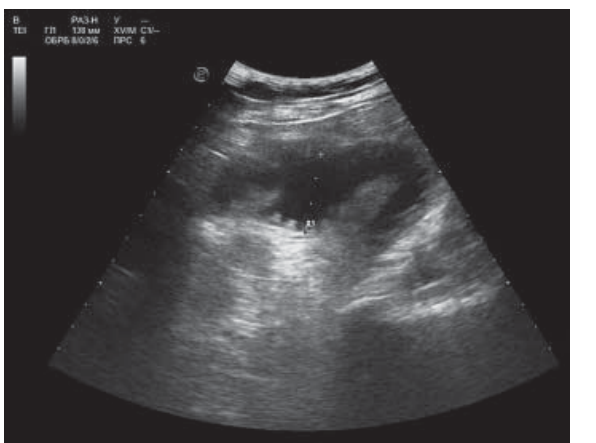

Рис. 1.

УЗД.

Ознаки фіксації петлі тонкої кишки до черевної стінки. нах черевної порожнини (ОЧП) [1, 2].

У 55 - 70\% пацієнтів після хірургічного втручання на ОЧП виникає спайковий процес, що може спричинити гостру спайкову непрохідність кишечнику [3, 4].

Використання УЗД в діагностиці захворювань ОЧП поширене завдяки доступності і відносно невисокій вартості дослідження, відсутності побічних реакцій, неінвазивності процедури, можливості моніторингового дослідження.

Використання цієї методики при СХО розширюе можливості іiі діагностики, вибору доступу й виду хірургічного втручання у хворих [5 7].

\section{МАТЕРІАЛИ I МЕТОДИ} ДОСЛІДЖЕННЯ

Для дослідження у 290 хворих використаний апарат ESAOTE MyLabAlpha (Італія) 3 лінійним (AL
2442) і конвексним (АС 2 541) датчиками. Вимогами до виконання УЗД були проведення процедури натщесерце, дотримання безшлакової дієти, застосування ферментних препаратів.

3 метою отримання об'єктивних даних Узд проводили під різним тиском і кутами нахилу датчика по відношенню до досліджуваних ділянок, у різних положеннях тіла пацієнта, на тлі дихальних екскурсій. Результати порівнювали $з$ даними рентгенологічного дослідження комп'ютерної томографії та інтраопераційних знахідок.

Для виявлення спайок між ОЧП та черевною стінкою дослідження проводили в ділянці післяопераційного рубця у фазі «вдих-видих-затримка дихання» 3 переходом на інші ділянки черевної стінки. Значення мала відстань між органом і датчиком, а також його зміни при зміні положення тіла пацієнта. 


\section{РЕЗУЛЬТАТИ}

\section{ТА ÏХ ОБГОВОРЕННЯ}

На підставі аналізу результатів дослідження відзначено, що відстань між датчиком і ОЧП менше 5 мм є ознакою спайок між черевною стінкою і органом, більше 10 мм - ознакою відсутності спайкового процесу в досліджуваній ділянці, 5-10 мм свідчила про можливу наявність спайок у вигляді тяжів, плівок (рис. 1).

Під час оперативного втручання у 273 хворих підтверджено фіксацію ОЧП до черевної стінки.

Під час УЗД у 129 пацієнтів з приводу СХО виявлене потовщення стінки тонкої кишки в ділянці спайкового процесу (рuc. 2).

Під час виконання УЗД виявляли розширення петель кишечнику, маятникоподібні рухи вмісту кишечнику, що було достовірною ознакою його непрохідності.

3 метою визначення результативності консервативних заходів, спрямованих на усунення гострої спайкової непрохідності кишечнику, під час УЗД критеріями були наявність вільної рідини в черевній порожнині, розширення петель тонкої кишки більше ніж на 2 см на тлі спалих петель, перистальтичні хвилі кишечнику у вигляді маятникоподібних руxiв.

Вільна рідина в черевній порожнині виявлена у 24 хворих, розширення петель тонкої кишки більш ніж на 2 см на тлі спалих петель кишечнику - у 93 (рис. 3), порушення функції тонкої кишки в ділянці спайкового процесу у вигляді перистальтичних хвиль, маятникоподібних рухів - у 84.

\section{REFERENCES}

1. Boys $\mathrm{F}$. The prophylaxis of peritoneal adhesions. $\mathrm{Br} \mathrm{J}$ Surg. 2012;89(1):50-6.

2. Barmparas G, Branco BC, Schnuriger B, et al. The incidence and risk factors of post-laparotomy adhesive small bowel obstruction. $J$ Gastrointest Surg. 2010;14(10):1619-28.

3. Voskanyan SE, Kyzlasov PS. Profilaktika spaechnoy bolezni bryushnoy polosti - sovremennoe sostoyanie problemy. Vestnik khirurgii im. I. I. Grekova. 2011;(1):93-6. [In Russian].

4. Fazio VW, Cohen Z, Fleshman JW, et al. Reduction in adhesive smallbowel obstruction by Seprafilm adhesion barrier after intestinal resection. Dis Colon Rectum. 2006;49:1-11.

\section{вИсновки} 4,1\% пацієнтів. втручання.

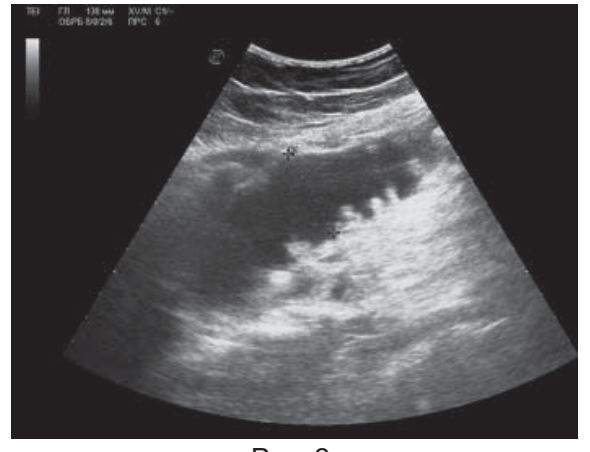

Рис. 2.

УЗД.

Потовщення стінки кишки в ділянці спайкового процесу.

Ультразвукова семіотика у пацієнтів при СХО

\begin{tabular}{|lcc|}
\hline \multicolumn{1}{|c|}{ Симптом } & \multicolumn{2}{c|}{ Кількість хворих } \\
\cline { 2 - 4 } & абс. & $\%$ \\
\hline Фіксація порожнистого органа до черевної стінки & 273 & 94,1 \\
\hline Потовщення стінки кишки в ділянці спайкового процесу & 129 & 44,5 \\
\hline Розширення петлі тонкої кишки в ділянці спайкового процесу & 93 & 32,1 \\
\hline $\begin{array}{l}\text { Маятникоподібна перистальтика кишечнику в ділянці } \\
\text { спайкового процесу }\end{array}$ & 84 & 29,0 \\
\hline Вільна рідина в черевній порожнині & 24 & 8,3 \\
\hline
\end{tabular}

За відсутності акустичного вікна застосовували метод відкритого введення першого троакара. Під час оперативного втручання $з$ приводу СХО дані УЗД підтверджені в усіх пацієнтів. Ознаки СХО виявлені у 94,1\% пацієнтів (див. таблицю).

1. За даними УЗД СХО виявлена у

2. Проведення УЗД в динаміці дозволяє контролювати і своєчасно визначати показання до оперативного

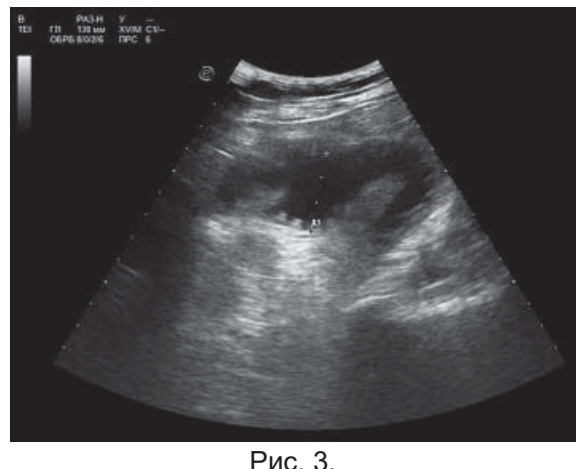

УЗД.

Розширення петель тонкої кишки
3. У хворих при динамічній непрохідності кишечнику повторне проведення УЗД дозволяє уникнути виконання непотрібної релапаротомiï.

4. Використання УЗД в клінічній практиці сприяє виявленню ознак $\mathrm{CXO}$, акустичного вікна для введення троакара під час виконання мініінвазивних втручань, що забезпечує своєчасну діагностику та попередження ятрогенного пошкодження ОЧП.
5. Zaporozhchenko BS, Shishlov VI, Zubkov OB, i soavt. Diagnosticheskie i takticheskie voprosy ranney ostroy spaechnoy neprokhodimosti kishechnika. Klinichna khirurhiia. 2004;(12):36. [In Russian].

6. Starkov YuG, Domarev LV, Shishin KV, Solodinina EN. Ultrazvukovoe kartirovanie vistseroparietalnykh srashcheniy bryushiny pered laparoskopicheskimi operatsiyami. Meditsinskaya vizualizatsiya. 2002;(4):22-6. [In Russian].

7. Ouaissi M, Gaujoux S, Veyrie N, Deneve E, Brigand C, Castel B, et al. Post-operative adhesions after digestive surgery: their incidence and prevention: review of the literature. Journal of Visceral Surgery. 2012;149:104-14. 